\title{
Effecting Change: Civil Servants and Refugee Policy in 1970s Canada
}

\author{
MICHAEL J. MOLLOY AND LAURA MADOKORO
}

\begin{abstract}
Historic transformations took place in Canada's refugee programs in the 1970s. Through the eyes of Michael Molloy, then director of Refugee Policy in the Department of Manpower and Immigration, this article explores the political climate that led to innovations in refugee admissions and resettlement efforts as they evolved from subjective, ad hoc affairs in the immediate post-war period to integral aspects of Canada's immigration program by the late 197os. By considering the role of individual members of the Department of Immigration, including the visa officers stationed overseas who were responsible for determining admissions and immigration officials working in policy units in Ottawa, this article points to the important role that individuals played in delivering programs that ultimately shaped the direction of refugee admissions and resettlement in Canada and the country's engagement with the international refugee regime.
\end{abstract}

\section{Résumé}

Au Canada, les programmes relatifs aux réfugiés ont fait l'objet de modifications historiques dans les années $70 . \AA$ travers le regard de Michael Molloy, qui était alors Directeur de la politique relative aux réfugiés au Département de la Main d'ouvre et de l'Immigration, cet article détaille le climat politique qui a conduit aux innovations concernant l'admission des réfugiés et les efforts de réinstallation, alors que ce sujet passait du statut d'affaires ponctuelles et subjectives de l'après-guerre immédiat à celui de perspectives indissociables du programme d'immigration du Canada à la fin des années 70 . En envisageant le rôle des membres $d u$ département de limmigration, y compris celui des agents des visas établis à létranger et responsables sur le terrain de l'admission des immigrants et celui des agents de l'immigration travaillant à Ottawa dans diverses unités de la politique, cet article fait apparaître en premier lieu le rôle important joué par les personnes dans la délivrance des programmes en vertu de la Politique sur les minorités opprimées qui, ultimement, a façonné la direction de l'admission des réfugiés et de leur réinstallation au Canada. Il met par ailleurs en évidence l'engagement du pays envers le régime international des réfugiés.

\section{Introduction}

ince the Second World War, refugee policy in Canada has evolved dramatically from an ad hoc, often disin$\checkmark$ terested approach to global displacement to an integral part of Canada's immigration programs. This article proposes that the key period of change occurred in the 1970s. Using the recollections of Michael Molloy, former director of Refugee Policy in the Department of Manpower and Immigration, this article suggests that the reforms that led to the development of the formal refugee programs (including the under-explored Oppressed Minority Policy), which facilitated the admission of refugees beyond the traditional focus on Europe, were highly influenced by those doing and managing resettlement.

In recent years, scholars have increasingly focused on the role that so-called brokers have played in the facilitation of global migration, historically and presently. ${ }^{1}$ The focus of this scholarship has generally been on how legal and 
illegal migration relied, and continues to rest, on networks of informed friends, family, and entrepreneurs. Increasingly, however, scholars are considering the role that individuals within the system play in facilitating or discouraging crossborder migration. ${ }^{2}$ Building on this approach, this article considers the role of civil servants in transforming Canada's refugee policy during the critical decade of the 1970s as Canadian politicians and the general public became increasingly attuned to refugee movements globally, responding to crises in Latin America, Africa, and Southeast Asia.

Michael Molloy's career provides a unique vantage point from which to consider how a single broker's experience is simultaneously informed by, while itself informing, the migration of people across borders. Molloy's career inter sected with key chapters in the evolution of the Canadian government's response to refugees. His career with the immigration foreign service began in 1968, the year before Canada committed to the 1951 Refugee Convention and 1967 Protocol. He served as a visa officer in Tokyo, Beirut, and Minneapolis, and was director of refugee policy from 1976 to 1978. His time in the field, as well as a senior manager, coincided with major population upheavals in Africa, Southeast Asia, and Latin America, to which the Canadian government ultimately responded. When a major refugee movement occurred in Southeast Asia in 1979, Molloy coordinated the Indochinese Refugee Task Force, overseeing the selection, reception, and settlement of 60,000 Indochinese refugees.

Now that he is president of the Canadian Immigration Historical Society, Molloy's attention has turned to reflecting on and documenting Canada's past engagement with immigration and refugee issues. This has involved facilitating the preservation of historic documents such as those of the Ugandan Asian refugees of 1972 as well as the organization of workshops on the history of refugees in Canada. 3 This article emerges from Molloy's interest in documenting the events and initiatives that influenced the transition from a reactive, ad hoc approach to refugees to a formal, law-based refugee policy informed as much by experience as principle. Working in collaboration with Laura Madokoro, a historian interested in refugee policy and the politics of humanitarianism, the article evolved to consider how the experience of one individual might suggest a broader phenomenon in how migration and policy were mutually constituted in the post-war period. The collaboration involving a series of conversations, fact-checks, and revisions (between September and November 2016) and presented an interesting meeting of academia, professional expertise, and a shared interest in better contextualizing the significance of Canada's engagement with the global refugee regime.

\section{Effecting Change}

It was 1969, the year Canada signed the UN Convention relating to the Status of Refugees and the 1967 Protocol, that heralded a decade of change in Canada's approach to the world's refugees that included a more sustained and innovative approach to refugee resettlement. To understand the significance of the bureaucratic interventions in these years, it is necessary to briefly consider the tenor and character of Canada's response to refugees in the immediate aftermath of the Second World War.

Responding to massive unemployment during the Great Depression and the demands of the Second World War, the federal government severely curtailed immigration for fifteen years. By the end of the war, Canada had only a tiny, enforcement-oriented immigration service situated in the Department of Mines and Resources. ${ }^{4}$ Little remained of the robust immigration program of the early twentieth century, which saw a million people arrive between 1911 and 1913. The government's priority at the end of 1945 was to repatriate hundreds of thousands of Canadian servicemen and women and 50,000 "war brides." Aside from 4,500 Polish war veterans destined for Canadian farms after refusing to return to Communist Poland in 1946, few refugees were admitted.

Although the federal government was generally disinterested in the plight of refugees in the immediate postwar period, by 1947 resource-sector labour shortages were growing, and the government was pressured by employers and by religious and community leaders to reopen European immigration for refugees and war-separated families. ${ }^{5}$ These pressures, and the government's desire to play a role in the post-war international community, led to a decision to admit refugees from Europe. The creation of the International Refugee Organization (IRO) to resolve the refugee problem provided the opportunity. ${ }^{6}$ Working with the IRO in occupied Germany and Austria and with the Canadian Christian Committee for Refugees in other parts of Europe, the Canadian Government Immigration Mission facilitated the admission of 163,000 displaced persons. ${ }^{7}$

The federal government's interest in displaced persons to address labour shortages coincided with developments on the international stage. On 8 August 1949, the UN's Economic and Social Council adopted Resolution 248(Ix) requesting the UN secretary-general to reconvene the Committee on Refugees and Stateless Persons. The committee, chaired by Canadian Leslie Chance, met from 16 January to 16 February 1950, and prepared the first draft of a refugee convention, which was revised and adopted within eighteen months. ${ }^{8}$ Despite Canadian involvement, the government declined to ratify the convention. The RCMP and the Immigration 
Department believed the convention would compromise the government's ability to control admissions and interfere with deportations, even on national security grounds. 9 Officials in External Affairs sought to overcome this opposition without success until the $1960{ }^{10}{ }^{10}$

Ambivalence towards international refugee initiatives contributed to an approach that was far from cohesive. Refugees were not considered a permanent or pressing issue. In 1953, the Immigration Department optimistically announced that it would no longer report separate refugee statistics, assuming that refugees were a thing of the past. ${ }^{11}$ That assumption was, of course, illusory. The 1956 Hungarian uprising attracted strong media attention, and the public demanded action on behalf of the "freedom fighters." 12 The Liberal government hesitated: security advisers warned about Soviet infiltrators; Immigration officials doubted Hungarians could successfully adapt. The director of immigration warned against "non bona fide refugees," whom he described as "members of the Hebrew race."13 After dithering for a month, the government acted. Immigration Minister Jack Pickersgill flew to Vienna and personally directed an operation that set aside normal selection, security, and medical criteria and brought 37,000 Hungarian refugees to Canada. The Hungarian crisis set a precedent that was cited for decades: it established the notion in the minds of policymakers and the public that Canada could and would mount special, if ad hoc, resettlement operations when circumstances and public support dictated. ${ }^{14}$

By the early 1960 s the federal government concluded that the country's race-based immigration policy no longer fit with how political leaders and elites saw Canada's place in the world. Moreover, an immigration program shaped by racial preferences contradicted Conservative Prime Minister John Diefenbaker's Bill of Rights. Reform began when the minister of citizenship and immigration, Ellen Fairclough, brought in the 1962 immigration regulations that cancelled the most egregious regulations barring nonEuropean migrants (though significant barriers remained for family class migrants), and created migration opportunities for those whose education, training, skills, or special qualifications made them likely to "successfully establish" in Canada. ${ }^{15}$ This was a critical step, but it was left largely to individual immigration officers to apply the policy on a case-by-case basis. There was substantial variance in how individual officers proceeded.

Over the course of the post-war period, the sensibilities of Canada's immigration service were fluctuated. As Harry Cunliffe, one of the veterans who joined the Immigration Department in 1947, described his contemporaries' attitude, "We were among the first of our generation to appreciate the value of immigration to Canada. We developed a respect for our clientele ... and because we had served abroad in World War II, we understood the hardships of travel, separation from family and of an uncertain future."16

In 1957 the Department of Citizenship and Immigration began professionalizing its overseas service through university recruitment. This led to the selection of employees who often had a different sense of what constituted a desirable immigrant. As Molloy recalls, shortly after the 1962 regulations came into place, the department undertook a campaign to recruit tool and die makers. At one of the smaller offices in the United Kingdom, a post-1957 recruit interviewed, accepted, and extended a transportation loan to a well-qualified tool and die maker who happened to be Jamaican. The officer in charge (oIC) objected-the program was not for Jamaicans. The young officer demanded to know where that was stated in the regulations. The oIc had to admit it was not in the regulations, but "everyone knew" it was not for "coloured people." The young officer stuck to his guns. ${ }^{17}$ As Molloy explains, in the oIC's defence, the 1962 changes, profound if incomplete, were made with no publicity, causing some officials to conclude that politicians were not serious and were counting on civil servants to maintain the status quo. ${ }^{18}$ However, for the most part neither the veterans recruited after the war nor the university-educated officers recruited from 1957 onward had difficulty adapting to the new open policy.

Even with the regulatory changes and new recruitment strategies, Canada's immigration program continued to be critiqued. As the 1960 s progressed, the lack of transparency in the immigration system gave rise to increasing accusations of arbitrariness and racism from scholars and the media. A precursor for substantial change was the official recognition that refugees were not just potential immigrants but, rather, were victims of persecution who should be considered in a class of their own. The first public indication of this transformation appeared in the widely circulated 1966 white paper on immigration, which stated, "Because of the peculiar problems of refugees, and to permit the ordinary standards and procedures applicable to immigrants and non-immigrants to be set aside or relaxed on their behalf, it is proposed to introduce separate legislation to help refugees. It is also intended that Canada should accede to the 1951 International Convention on the Status of Refugees."19

Further reform was clearly needed, and it fell to a former immigrant and journalist with a passion for equity, fairness, and reform, Deputy Minister Tom Kent, to drive the change. $^{20}$ The result was a point system, introduced 1967 in an effort to achieve more consistency and objectivity in immigrant selection. ${ }^{21}$ With the concomitant expansion of the overseas immigration network, Canadian officials were soon applying identical criteria to applicants in 100 countries 
under a "universal" immigration system. The reorganized and renamed Department of Manpower and Immigration became the instrument that facilitated rapid demographic change. According to Molloy, this was neither by accident nor design:

I do not believe that any of those, Kent included, who were associated with the changes really understood how quickly or how profoundly Canada would change. My 1968 class of trainees were briefed by officials who told us that Canada's complexion was going to change from "white to brown." I don't think any of us quite believed it, even though we were being trained to go out into four corners of the world to recruit immigrants on the basis of the point system rather than race or colour. The government introduced a profound policy change, and the Immigration Department switched overnight from being the guardian of the all-white status quo, to facilitating the movement of immigrants from every continent. The new direction was quickly accepted. ${ }^{22}$

As suggested in the white paper, Canada also moved to sign the 1951 Un Convention relating to the Status of Refugees and the associated protocol, which opened for signature in 1967. The 1967 Protocol removed both the temporal and geographic limitations to the Convention, making it globally applicable. Canada signed the Convention and Protocol in 1969. There was little if any public pressure to do so, and little fanfare when the decision to sign was announced. With External Affairs taking the lead, the impetus came mainly from within the government, driven by a sense that Canada, asserting leadership within the UN, should at last ratify the international refugee instruments. ${ }^{23}$ With "universality" the new theme of Canada's immigration policy as a result of further reforms in 1967 , opposition in the department evaporated.

When the government created the Department of Manpower and Immigration in 1966, it brought together the immigration program with elements from the Department of Labour and the National Employment Service. Created to achieve a closer alignment of immigration and labour market needs, the goals of the new department also included ensuring that:

- Canada discharges international obligations for the assistance of refugees.

- There is no discrimination by race, country or religion.

- Canada respects the interests of other countries as to the immigration of their citizens. ${ }^{24}$

Injecting responsibility for refugees into the "DNA" of its new flagship department, the government assigned clear and formal responsibility for the refugee issue to the new minister of manpower and immigration and his deputy minister.

In signing the Convention and Protocol and creating departmental structures to facilitate refugee policies and programs, Canadian authorities were turning away from the previous ad hoc reaction to refugees. This reflected an overall trend to formalize and regulate the functioning of government, but the changes in the government's approach to refugee policy were about more than regularizing policies. ${ }^{25}$ They were also symbolic of the tone that Prime Minister Pierre Trudeau wanted to set for the country on the world stage. $^{26}$

Having signed the Convention and Protocol, the government moved rapidly to consider the implications. On 27 July 1970 Cabinet discussed a memorandum titled "Selection of Refugees for Resettlement in Canada" submitted by Minister Allen MacEachen. It began by stating a problem and an objective that demonstrated a desire to take Canada's refugee programs in a new direction:

Problem: While Canada's immigration policy was placed on a universal basis with the introduction of the new Immigration Regulations in 1967 [point system], the selection of refugees has continued to favour persons of European origin.

Objective: The purpose of this memorandum is to establish a refugee program which will admit refugees who have good prospects of settlement in Canada without regard to geographic origin. ${ }^{27}$

On the basis of the memorandum, Cabinet made three key decisions. First, it adopted the 1951 Convention's refugee definition, as "universalized" by the Protocol, for resettlement and protection: refugee selection would no longer be restricted to Europe. Second, the point system would be used to assess prospects for successful establishment, but Cabinet stressed that officers were expected to use their discretionary authority to override the system in favour of refugees given the assistance available on arrival. ${ }^{28}$ Finally, Cabinet approved an Oppressed Minority policy that provided for the selection of oppressed people who were not Convention refugees because they were still in their home countries.

That Cabinet memorandum marked the emergence of a formal Canadian refugee policy. It was first step in what future minister of manpower and immigration Robert Andras, architect of the 1976 Immigration Act, would characterize as "a discernible effort to envelope Canadian refugee activity in a frame-work of policy and principle guidelines." ${ }^{29}$ Cabinet's decision was communicated to the staff of the Immigration Department in Operations Memorandum 17 (OM17) of 2 January 1971, which laid out in considerable detail the implications of the Convention and the Protocol, and how refugee status determination and selection were to be implemented by Canadian officials abroad and by a new status determination committee in Canada. ${ }^{30}$ Molloy recalls amending his manual to add Ops Memo 17: "I was in Tokyo 
when it came out, and it had little relevance to me, as we never saw refugees in Japan in those days. The Cabinet document it was based on was shrouded in Cabinet secrecy, so we knew little about the background of the decision except that it related to signing the Convention." ${ }^{1}$

The Oppressed Minority policy informed the Canadian response to refugees in Uganda, Chile, and Argentina. The Uganda operation was triggered by a British request for help when, on 4 August 1972, Ugandan President Idi Amin announced the expulsion of the country's Asian minority. Prime Minister Trudeau declared that Canada would "offer an honourable place" to Ugandan Asians affected by the edict. The Uganda operation demonstrated the utility of the Oppressed Minority policy, as those ordered expelled were still in Uganda and therefore outside the UNHCR's mandate. Molloy recalls,

When we arrived in Kampala, the UNHCR was not present. Our initial instructions issued by the Cabinet on August 22, 1972 were to select up to 3000 people who met ordinary immigration selection criteria. However, in response to team leader Roger St. Vincent's daily reporting on what we were observing on the ground, six days after the operation started, Cabinet issued new instructions stressing the humanitarian nature of the operation and the need to focus on people with nowhere to go. ${ }^{32}$ When the Ugandan government subsequently began stripping Asians of Ugandan citizenship, we were instructed to consider Asians with Ugandan passports as de facto stateless. It is unclear whether the government formally invoked the Oppressed Minority policy, but on the front line we were guided by it. 33

Five thousand people were moved to Canada in two months. ${ }^{34}$ In 1973, now in coordination with UNHCR, Canada accepted another 2,000 Asians from camps in Europe. According to Molloy,

It was interesting to see how the policy evolved over the first few weeks of the operation ... it was clear to my boss, Mr. St. Vincent, and myself that those in Ottawa had little understanding of what was evolving and they knew it. As the weeks rolled by, the tone of the communications became more and more concerned, even frantic, about not leaving anyone behind. In the final weeks we were told we could take 300 "humanitarian cases" but it was a too late, and in any case we combed the applications repeatedly to identify those who were stateless and had accepted every disabled person and everyone in personal danger as they came through the door. ${ }^{35}$

In 1973, following the violent overthrow of the democratically elected regime of Salvador Allende in Chile, thousands of people were brutally targeted by the new regime. In Canada, church groups-many of which had been active in Latin America as part of the liberation theology movement-lobbied the federal government to intervene on a scale at least akin to what had taken place in Uganda the previous year. Dogged by controversy from the start, the Chilean movement was politically difficult to manage and technically complex to deliver. ${ }^{36}$ The leaking of a sympathetic assessment of the coup by the Canadian ambassador to Chile outraged churches and human rights advocates who coalesced into an assertive refugee advocacy community. In the following years (and under continuous criticism), staff from the Department of Manpower and Immigration extracted distressed Chileans in three streams: Chilean Convention refugees from neighbouring countries (referred by UNHCR), Chileans directly from Chile under the Oppressed Minority policy (often referred by the Catholic Vicaria de la Solidariedad), and 200 political prisoners (plus families) direct from Chile. A fourth stream of Chilean asylum seekers arrived at Canadian airports providing work for a new interdepartmental committee in refugee status determination. As Molloy recalls,

In the Chilean and Argentinian cases we had three tools we could use for those in different circumstances: the Convention definition for those who had fled persecution to neighbouring countries; the Oppressed Minority policy fit people hiding from the authorities in their own country; and the Political Prisoner Program, an offshoot of the Oppressed Minority policy, was for those incarcerated by the military regimes. I came on the scene in 1976, and there were still lots of problems-mainly to do with security screening-but providing guidance to the visa officers and dealing with the critics convinced me that we needed to be able design definitions to meet the characteristic of differing refugee problems rather than trying to cram them all into the Convention definition. ${ }^{37}$

The role of visa officers in interpreting and influencing policy would be critical again two years later when the fall of pro-Western governments in Laos, Cambodia, and Vietnam in 1975 precipitated the flight of hundreds of thousands of Indochinese migrants over land and sea. As the South Vietnamese regime crumbled, strict exit controls thwarted Canadian efforts to evacuate relatives of Vietnamese in Canada. At the initiative of Charles Roger, the manager of Manpower and Immigration's office in Hong Kong, 3,500 families were sent letters promising visas if they could reach a Canadian diplomatic facility. An American request led to a commitment to accept 3,00o Convention refugees from evacuation camps, first in Guam, then the United States and elsewhere. Nine thousand Indochinese refugees arrived in Canada over the next three years. The arrival of a notorious Vietnamese general in Montreal (to join his family) created a firestorm of criticism and killed political and public support 
for Indochinese refugees. ${ }^{38}$ Molloy remembers, "When I took over the Refugee Policy Division in September 1976, the challenge was to sustain some kind of minimal involvement in the face of public indifference. This we did by focusing on relatives and squeezing every last number out of the commitment to 3,000 Indochinese Convention refugees until the numbers started to build up in 1978. The indifference of the refugee lobby, deeply divided between pro-Eastern European and pro-Latin American groups, was disappointing." 39

The rapid succession of refugee problems-Uganda, Chile, and the first phase of Indochina, as well as a growing stream of people escaping communist Eastern Europe-demonstrated to officials that refugee crises were no longer infrequent events. The Liberal government decided it was time to overhaul Canada's outmoded immigration legislation. Robert Andras, a tough, competent minister, was given the mandate to make it happen. His deputy minister, Alan Gottlieb, and the official chosen to spearhead the project, Richard Tait, were talented thinkers from External Affairs whose experience at the Canadian Permanent Mission to the UN in Geneva had exposed them to refugee problems and the issue of Canada ratifying the Refugee Convention.

Amongst all this talent, Kirk Bell stood out in this period of change, innovation, and purposeful engagement with the global refugee regime. Unpopular with the rank and file, Bell won the loyalty of those working most closely with him for his determination, strategic vision, and thoughtful approach to the department's many critics. As Molloy recalls, "My first year with him was the hardest of my career, but his strategic vision of Canada's refugee role, combined with my first-hand experience, was a good fit. At the time, he was director general of recruitment and selection, and his mandate covered the entire range of issues relating to who should be able to come to Canada for permanent or temporary reasons, but refugees and Canada's responsibilities for refugees globally were his passion. It was his vision that shaped the refugee policy and programs that emerged from the 1976 Immigration Act." 40

Bell was determined to put Canada's refugee effort on a firm legal and institutional footing. In 1975 he established a Refugee Policy Division (REFPOL) staffed by a director, a chief, and a secretary who would:

- lead implementation of the refugee provisions of the (1976) Immigration Act,

- generate options on emerging refugee issues,

- provide policy guidance to refugee operations,

- liaise with advocacy groups and communities,

- oversee the Interdepartmental Committee on Refugee Status Determination, and

- spearhead the Immigration Department's relations with implementation of the refugee pro, the
Intergovernmental Committee on European Migration, and international humanitarian NGOs. ${ }^{41}$

During this time, units responsible for refugee matters were created in External Affairs and the Canadian International Development Agency, and an experienced immigration foreign service officer was assigned to the Canadian Mission in Geneva to coordinate Canadian relations with UNHCR. This proved to be a potent combination for engaging international efforts on refugee issues. In its impact, the establishment of these refugee units was as important as the Cabinet decisions of 1970: there were now clusters of civil servants in three departments focusing exclusively on refugee issues.

REFPOL's work was undertaken within the framework of the 1976 Immigration Act, which came into force in 1978. The drafting of the Act was preceded by wide public consultations. Hundreds of submissions were received and a joint parliamentary committee held public hearings across the country. The refugee advocacy community took full advantage of the consultative process to make known their views on asylum and resettlement. As Molloy recalls, "On asylum, they wanted a system that allowed the asylum seeker to put his or her case directly to the relevant decision-maker, something the government of the day considered to be too costly. On resettlement they wanted a transparent law-based system and meaningful way to influence the government's priorities. On private sponsorship, which we were testing with a couple of pilot projects, some of more influential advocates were opposed, but grassroots consultations from Halifax to Vancouver revealed real interest." 42

The 1976 Immigration Act contained a large number of refugee provisions. The Convention definition, adopted by Cabinet in 1970, was embedded in section 2(1) and among the objectives of Canada's immigration policy was the following:

3.g to fulfill Canada's international legal obligations to refugees and to uphold its humanitarian traditions with respect to the displaced and the persecuted. ${ }^{43}$

Section 4(2)(b) set the parameters under which a Convention refugee could remain in Canada, while section 6(2) established the framework for the selection of Convention refugees from abroad, along with what became known as designated classes. It also established the regulatory basis for private sponsorship of refugees and designated classes. 44

Consultations with the Standing Conference of Organizations Concerned with Refugees (predecessor of the Canadian Council for Refugees) led to a decision to drop the point system per se from the overseas refugee selection system. The officials designing the new resettlement system were constrained by section 6(1) of the Act requiring that refugees, 
like other immigrants, "be able to become successfully established in Canada." The new rules instructed visa officers to consider the "norms of assessment" (age, education, occupation, presence in Canada of relatives or sponsors, English or French competency, etc.) without assigning points, and to consider public and private assistance available to refugees on arrival. While it did not meet all the advocates' wishes, the system proved highly elastic in accommodating a broad spectrum of refugees in the succeeding decades.

The cornerstone of the new resettlement system, the Convention Refugee in Need of Resettlement Class rested on a three-stage process. The first was eligibility, i.e., compliance with the Convention definition. The second, admissibility, the potential for successful establishment. And finally statutory requirements-medical and security/criminality criteria. Critically, given the limitations of the Convention refugee definition, REFPOL staff seized the opportunity offered by section 6(2) of the Act to create alternative humanitarian designated classes, "the admission of which would be in accordance with Canada's humanitarian tradition with respect to the displaced and persecuted." 45 The thinking behind the three designated class provides a good example of how operational experience and policy objectives interacted during this time.

Ironically, while the Convention definition had be designed for people fleeing persecution in the East European community bloc, many of those presenting themselves for resettlement at Canadian embassies in Rome and Vienna by the 1970 s had either been given permission by the communist regimes to depart for Israel or to travel for business or cultural purposes in Western Europe. There were powerful community interests supporting their resettlement in Canada, but in many cases the Convention definition did not fit the circumstances, not least because many objected to being classified as refugees. ${ }^{46}$ As a result, Molloy asked Raphael Girard, then manager of the visa office in Rome, to draft a designated class regulation to more precisely fit the circumstances of the East Europeans his staff were seeing. The resulting Self-Exiled Persons Designated Class shifted the focus from persecution to the reality that these people were being systematically stripped of the citizenship by their countries of origin. 47 Girard's draft regulation provided that the "self-exiled" be treated as Convention refugees in need of resettlement in all other regards, including eligibility for private sponsorship. It became the template for design of the other designated classes, remaining in effect until the Soviet Union collapsed.

Because the Oppressed Minority policy created by Cabinet in 1970 had proved to be such a useful tool in Uganda and Latin America, the Convention definition minus the requirement to be outside one's country became the core of the Political Prisoner and Oppressed Persons Designated Class (рРор). The Indochinese Designated Class sidestepped the issue of individualized persecution because of the brutal protection calculus in Southeast Asia. Whatever their motivation for fleeing, if large numbers of boat people were not resettled rapidly, the Southeast Asian asylum countries would close their shores and people would die.

With the designated classes the government settled the question of eligibility and signalled its objectives to the frontline officers with great clarity. It was left to officials to assess admissibility. In case of the Self-Exiled Designated Class, the interests of Canada's Eastern European and Jewish communities and their record in settling their compatriots or co-religionist, along with Canada's Cold War stance, were critical. For the pPop Class it was the proven utility of a policy that permitted intervention for people facing oppression but unable to flee across borders. With the Indochinese Designated Class, the need to move people quickly to save lives and a conviction that the situation in Southeast Asia was about to become much worse, were critical. Field-based operational experience helped shape the regulatory framework governing refugee admissions to Canada. This in turn supported the government's efforts to further formalize the overall structure of the country's immigration and refugee programs.

The 1976 Immigration Act required the government to consult widely about immigration intake and announce each year's immigration "levels" in advance. The traditional view, that it was futile to plan refugee intake from year to year because new refugee crises were impossible to foresee, was obsolete. The Department of Manpower and Immigration was concurrently running multi-year resettlement programs in South America, Europe, and Southeast Asia and was beginning to ponder expanding into Africa. ${ }^{48}$ It was therefore proposed by Molloy and Ian Timonin, who was in charge of levels planning, that the department should seek Cabinet approval for those continuing programs once a year, rather than piecemeal, and to deal with unexpected crises as they arose. This led to the insertion of an Annual Refugee Plan into the Annual Immigration Levels Plan. The planning process would include consultations with provincial governments, churches, and NGOs, anchored by input from UNHCR.

The first Annual Refugee Plan, submitted to Cabinet in December 1978, came hard on the heels of Minister Bud Cullen's intervention on behalf of Indochinese refugees stranded on the derelict freighter the Hai Hong in November 1978, and a consultation on the emerging Indochinese refugee crisis hosted by UNHCR in Geneva in early December. ${ }^{49}$ On 21 December 1978 Cabinet reviewed two documents. ${ }^{50}$ The first focused on the situation in Southeast Asia and recommended Canada accept 5,000 Indochinese refugees in 1979. Cabinet 
agreed. The second document sought Cabinet's endorsement of "the concept of an annual program for refugee resettlement, to be presented to Cabinet in conjunction with the annual immigration levels exercise."51 The document presented a rationale for the resettlement program. The premise of Canada's resettlement strategy was that "the strategy of our refugee program with respect to overseas selection is based on the premise that in a refugee producing situation there will always be more refugees in need of resettlement than we will be able to accept. Therefore, the objective of our strategy is to accept those in greatest need of our assistance who, at the same time, can successfully establish in Canada." 52

Criteria for evaluating the appropriateness of resettlement in emerging refugee situations included:

1. The situation has been examined by the Government of Canada, the UNHCR and the World Community and it is generally agreed that

a. there is a high level of need and

b. resettlement in countries such as Canada is both feasible and desirable in terms of hastening a complete solution and from the point of view of the individual well-being of refugees.

2. The situation is one where Canada for geographical or historical reasons can be considered as having responsibilities as a first line country of resettlement, e.g., Geographical-Western Europe, Historical-Eastern Europe.

3. The situation is of such seriousness that a general public consensus develops that Canada must make a contribution.

4. The situation is of serious concern to a segment of the Canadian community that is interested in Canada's international humanitarian role or in the well-being of a particular group abroad..$^{53}$

The strategy and criteria took into account international assessments of refugee crises confronting the global refugee regime and the interests of the Canadian public. The UNHCR was at the centre of Canada's resettlement strategy. The memorandum to cabinet declared,

It is our policy to consult with the UNHCR in identifying those among the refugee population who could most benefit from our help. This consultation is carried out at three levels:

i. With senior officials in Geneva as part of our role as a member of the UNHCR executive committee.

ii. With UNHCR field staff where problems exist or may occur in assessing the gravity of the situation and in identifying cases that will benefit from resettlement in Canada.

iii. With UNHCR representatives in Canada in discussing policy options and their operation implications. 54

The document affirmed the policy to go beyond the Convention definition when selecting refugees (the new designated class provisions) and to provide maximum flexibility to officers selecting refugees (exemption from the point system). The new sponsorship system "will allow us to select refugees who could not otherwise be considered capable of successful establishment." 55 The government endorsed the Annual Refugee Plan for fiscal year 1979/80. Refugee resettlement was now embedded in the federal budgetary cycle. As Molloy explains the significance of this initiative,

The agreement to include a refugee plan in the Annual Levels planning cycle meant that henceforth, whether there was a new crisis or not, the government of the day would review and determine Canada's resettlement activities for the coming year and trigger the necessary funding. Provincial governments and the settlement and advocacy communities had to be consulted, and the plan had to take account of UNHCR's priorities. That meant the UNHCR itself had to develop priorities. In 1981 I was assigned to the Canadian Mission to the UN in Geneva, where an important part of the work was to engage UNHCR and missions of the other resettlement countries in thinking about where and how resettlement activities could best be deployed: small steps toward the elaborate systems of resettlement consultations in place today. ${ }^{56}$

In the same historic month, December 1978, the Indochinese Designated Class Regulations became law, and the Mennonite Church decided to seek an agreement with the Immigration Department permitting the Mennonite Central Committee to authorize its congregations to sponsor refugees. A "Master Agreement" was signed by April; agreements with other churches quickly followed.

The elements of a sustainable, flexible, law-based resettlement program linking domestic interest and international priorities were now in place. It would be tested shortly in Southeast Asia, and 60,00o refugees would come to Canada as a result.

\section{Conclusion}

The people responsible for delivering immigration and refugee policy had a profound impact on how refugee policy evolved in Canada. A succession of resettlement programs (Uganda, Chile, and Indochina 1975-6) created operational expertise and competence, intensified interaction with UNHCR, and led to purposeful interdepartmental coordination. The refugee elements of the 1976 Immigration Act emerged from the policy and operational experience gained following ratification of the Convention and Protocol and the application of the Oppressed Minority policy. Experience gained with alternative definitions, selection criteria, status determination, and sponsorship was mined in designing the Act.

In the period from 1970 to 1978 , civil servants, working within the framework established by Cabinet, drove 
innovation: being required to transform and think more seriously about refugee issues was now part of the department's ongoing business. This included the rapid succession of disparate and far-flung refugee crises, the new challenge of dealing with asylum seekers on Canadian soil, a recognition that refugee reform at home positioned Canada to lead at the international level, and the emergence of a forceful advocacy community. The advocates certainly made themselves heard, and in the words of Kirk Bell, often "pushed us in the direction we wished to go." 57 However, the experience gained and the considerable freedom to interpret the policies developed in Ottawa were critical contributing factors in the evolution of Canada's refugee program from an ad hoc affair into an enduring framework for refugee admissions and resettlement.

\section{Notes}

1 Lisa Mar, Brokering Belonging: Chinese in Canada's Exclusion Era, 1885-1945 (New York: Oxford University Press, 2010); Khalid Koser, "Social Networks and the Asylum Cycle: The Case of Iranians in the Netherlands," International Migration Review 31, no. 3 (1997): 591-611; Khalid Koser and Charles Pinkerton, The Social Networks of Asylum Seekers and the Dissemination of Information about Countries of Asylum (London: Home Office, 2002), https:// www.researchgate.net/publication/240336001_The_Social_ Networks_of_Asylum_Seekers_and_the_Dissemination_ of_Information_About_Countries_of_Asylum.

2 Vic Satzewich, Points of Entry: How Canada's Immigration Officers Decide Who Gets In (Vancouver: UBC Press, 2016); Alison Mountz, Seeking Asylum: Human Smuggling and Bureaucracy at the Border (Minneapolis: University of Minnesota Press, 2010).

3 See, for example, "The Uganda Collection," MacOdrum Library, http://arc.library.carleton.ca/content/ugandacollection; and "The Indochinese Refugee Movement 197580 and the Launch of the Private Refugee Sponsorship Program Conference," http://indochinese.appso1.yorku.ca/ conference/conference.

4 For an excellent analysis of Canada's refugee policies in the immediate post-war period, see Geoffrey Cameron, “The Political Origins of Refugee Resettlement Policy: Insights from the Policy Process in Canada 1938-1951," 2014, http://imrc .ca/wp-content/uploads/2015/o1/Cameron-GunnAward2014.pdf.

5 For more on Canada's approach to displaced persons in Europe, see Julie Gilmour, "The Kind of People Canada Wants': Canada and the Displaced Persons, 1943-1953" (PhD diss., University of Toronto, 2009).

6 Cameron, "Political Origins," 4.

7 Even among Europeans, Canadian officials had hierarchical preferences. According to Harold Troper, officials gave preferences to "hardworking Nordic types" over Middle
Europeans, Slavs, or Jews. See "Canada and the Hungarian Refugees: The Historical Context," in The 1956 Hungarian Revolution: Hungarian and Canadian Perspectives, ed. Christopher Adam, Tibor Egervari, Leslie Laczko, and Judy Young (Ottawa: University of Ottawa Press, 2010), 181.

8 See Laura Madokoro, “Belated Signing”: Race-Thinking and Canada's Approach to the 1951 Convention relating to the Status of Refugees," in Dominion of Race: Rethinking Canada's International History (Vancouver: UBC Press, forthcoming).

9 In the early phase of the Cold War this was a serious concern. The defection of Soviet diplomat Igor Gouzenko in September 1945 revealed the extent of Soviet spying in Canada and the United States.

10 Gerald Dirks, Canada's Refugee Policy: Indifference or Opportunism? (Montreal and Kingston: McGill-Queen's University Press, 1977), 179-82. Canada did not join the UNHCR's executive committee until 1958. Dirks, "Canada and Immigration: International and Domestic Considerations in the Decade Preceding the 1956 Hungarian Exodus," in Breaking Ground: The 1956 Hungarian Refugee Movement to Canada, ed. Robert H. Keyserlingk (Toronto: York Lanes, 1993), 5 .

11 Department of Citizenship and Immigration, Annual Report 1953 (Ottawa: Queen's Printer, 1953).

12 Canadian and us media romanticized the Hungarians as "freedom fighters." Time magazine's "Man of the Year 1956" was a fictionalized portrait captioned "Man of the Year: Hungarian Freedom Fighter," Time, cover, 7 January 1957.

13 Troper, "Canada and the Hungarian Refugees," 190.

14 Dirks, "Canada and Immigration," 11.

15 See 1962 Immigration Regulations.

16 Robert H. Keyserlingk, ed., Breaking Ground: The 1956 Hungarian Refugee Movement to Canada (Toronto: York Lanes, 1993), 15.

17 As recalled by Michael Molloy, 6 October 2016.

18 Ibid.

19 Jean Marchand, Canadian Immigration Policy 1966: White Paper on Immigration, 19 October 1966, 23, Canadian Immigration Historical Society (cIHS) Collection.

20 Thomas Axworthy, “Tom Kent: A Life of Purpose," Toronto Star, 17 November 2011.

21 Under the point system, numerical values were assigned for age, education, occupation, skill level, intended destination, ability to function in French and/or English, presence of relatives in Canada, and arranged employment. The interviewing officer could award additional points for personal qualities like adaptability and motivation, and the applicant had to achieve fifty points overall to be accepted. The system included discretionary authority for instances where the interviewing officer believed the points did not reflect the applicant's true prospects for successful establishment. This was particularly important in the case of refugees.

22 As recalled by Michael Molloy, 2 November 2016.

23 Madokoro, “Belated Signing.” 
24 Department of Manpower and Immigration, Un-numbered Operations Memorandum: Department of Manpower and Immigration Goals, 9 May 1968, CIHs Collection.

25 The professionalization of the federal bureaucracy began in the 1960s, building on recommendations of the Glassco Commission, which operated for two years, publishing a final report in 1963. The Department of Immigration, spurred on by External Affairs, was ahead of the curve.

26 On Prime Minister Pierre Trudeau's foreign policy, see John English, Just Watch Me: The Life of Pierre Elliott Trudeau, 1968-200o (Toronto: Knopf Canada, 2009); Jack Granatstein and Robert Bothwell, Pirouette: Pierre Trudeau and Canadian Foreign Policy (Toronto: University of Toronto Press, 1991).

27 Memorandum to the Cabinet, "Selection of Refugees for Resettlement in Canada," 27 July 1970, RG 2, vol. 6373, file 1032-70, LAC.

28 The 1967 Regulations recognized there would be circumstances when the points total did not reflect an applicant's prospects for successful establishment. Officers could override the system by explaining their assessment in the box provided on the case-processing record (Imm 1067) and having it endorsed by their supervisor.

29 Robert Andras, "An Historical Sketch of Canadian Immigration and Refugee Policy," in The Indochinese Refugee Movement: The Canadian Experience, ed. Howard Adelman (Toronto: Operation Lifeline, 1980), 4.

30 Department of Manpower and Immigration, Operations Memorandum 17 (Rev) 2 January 1971, CIHs Collection.

31 As recalled by Michael Molloy, 2 November 2016.

32 St. Vincent had to report nightly from a bank of telephones in the lobby of the Apollo Hotel, and strangely enough, the same two French-speaking Ugandans pretended to be making calls from the telephones on either side of him every evening as well. When St. Vincent and Maurice Mitchell, the Ottawa-based director of operations, switched to joual (French-Canadian slang) to get a bit of privacy, the line was immediately cut. As recalled by Michael Molloy, 19 October 2016.

33 For a unique day-by-day account of the Ugandan Asian movement based on the log he kept at the time, see Roger St. Vincent, "Seven Crested Cranes: The Role of Canada's Mission to Canada," https://arc.library.carleton.ca/sites/ default/files/exhibits/seven-crested-cranes_2016.pdf.

34 ICEM set up an operation in Kampala to evacuate the residual Asian population in the building used by the Canadians. It was equipped with furniture donated by the departing Canadian team.

35 As recalled by Michael Molloy, 6 October 2016.

36 Suha Diab, "Fear and (In) Security: The Canadian Government's Response to the Chilean Refugees," Refuge 31, no. 2 (2015): 51-61.

37 As recalled by Michael Molloy, 2 November 2016.

38 There was extensive coverage across the country of General

Dang Van Quang's presence in Montreal; see, for example,
"Quang Still Here: Deportation Order Not Yet Carried Out," Ottawa Citizen, 5 February 1976.

39 As recalled by Michael Molloy, 2 November 2016.

40 As recalled by Michael Molloy, 6 October 2016.

41 Ibid.

42 Ibid.

43 See relevant sections in the 1976 Immigration Act.

44 For a detailed description of how the private sponsorship program was designed and marketed, see Michael Molloy, Peter Duschinsky, Kurt Jensen, and Robert Shalka, Running on Empty: Canada and the Indochinese Refugee Movement 1975-1980 (Montreal and Kingston: McGill-Queen's University Press, 2017), chap. 4.

45 See section 6(2) of the 1976 Immigration Act.

46 Raphael Girard, "Designated Classes: A Regulatory Device to Target Humanitarian Immigration," Canadian Immigration Historical Society Bulletin 47 (November 2005): 2-5, http://cihs-shic.ca/wp-content/uploads/2012/o6/Bulletin47-November-2005.pdf.

47 Self-Exiled Persons Class Regulation, soR/78-988 P.C. 1978 3663, 7 December 1978.

48 The longstanding Organization of African Unity policy (supported by the UNHCR) of discouraging third country resettlement of African refugees started to crumble as African asylum seekers began to arrive in Europe. The first commitment to resettle a modest 100 African refugees was included in the 1981 Annual Refugee Plan.

49 On the Canadian response to the Hai Hong, see Rene Paponne, The Hai Hong: Profit, Tears and Joy, rev. ed. (Ottawa: Department of Employment and Immigration, 2015).

50 Record of Cabinet Decision, "Annual Plan for Refugee Resettlement," Meeting of 21 December 1978 631-78RD; and Record of Cabinet Decision, "Indochinese Refugee Program-1979," Meeting of 21 December 1979 630-78RD, CIHS Collection.

51 Record of Cabinet Decision, "Annual Plan for Refugee Resettlement," Meeting of 21 December 1978, 631-78RD, cirs Collection.

52 Ibid.

53 Ibid.

54 Ibid.

55 Ibid.

56 As recalled by Michael Molloy, 6 October 2016.

57 As recalled by Michael Molloy, 2 September 2016.

Michael J. Molloy is president of the Canadian Immigration Historical Society and an honorary senior fellow at the University of Ottawa's Graduate School of Public and International Affairs. He can be contacted at joandmikeca@yahoo.com.

Laura Madokoro is an assistant professor in the Department of History and Classical Studies, McGill University. The author may be contacted at laura.madokoro@mcgill.ca. 